\title{
Intestinal microflora, morphology and enzyme activity in zinc-deficient and $\mathrm{Zn}$-supplemented rats
}

\author{
BY SUSAN SOUTHON, JENNIFER M. GEE, CATHERINE E. BAYLISS, \\ G. M. WYATT, NIKKI HORN AND I. T. JOHNSON \\ AFRC Food Research Institute Norwich, Colney Lane, Norwich NR4 7UA
}

(Received 30 September 1985 - Accepted 3 December 1985)

\begin{abstract}
1. Immature, male Wistar rats were given a low-zinc diet $(2 \mathrm{mg} / \mathrm{kg})$ for $22-24 \mathrm{~d}$. Control groups received a similar diet supplemented with $58 \mathrm{mg} \mathrm{Zn} / \mathrm{kg}$ either ad lib., or in amounts matched to the consumption of the $\mathrm{Zn}$-deficient group. Food consumption, rate of growth and food conversion efficiency were markedly lower in the $\mathrm{Zn}$-deficient group of rats compared with controls. Appetite, growth rate and food utilization improved dramatically over a subsequent $4 \mathrm{~d}$ period of $\mathrm{Zn}$ supplementation.

2. Morphological examination of samples of jejunum and ileum confirmed that $\mathrm{Zn}$ deficiency in the rat is accompanied by a reduction in villous dimensions and increase in villous density. After a short period of $\mathrm{Zn}$ supplementation, villous density and the basal width and maximum height of individual villi in the jejunum returned to normal. Similar changes occurred in the ileum but to a lesser extent.

3. Mucosal alkaline phosphatase (EC 3.1.3.1) activity was significantly lower in the small intestine of $\mathrm{Zn}$-deficient rats compared with $\mathrm{Zn}$-supplemented rats. Disaccharidase activities were lower in the $\mathrm{Zn}$-deficient group, compared with their feed-restricted counterparts, but were similar to values for ad lib.-fed controls. Tissue alkaline phosphatase and disaccharidase activitities were consistently higher after a $4 \mathrm{~d}$ period of $\mathrm{Zn}$ supplementation, compared with non-supplemented animals, but this increase was only significant for alkaline phosphatase.

4. Although there were striking similarities in the mucosal characteristics of gnotobiotic and $\mathrm{Zn}$-deficient rats, there was no indication that even severe dietary $\mathrm{Zn}$ depletion reduced the numbers of viable bacteria present in either the small or large intestine. Changes in intestinal structure and function resulting from variation in dietary $\mathrm{Zn}$ intake appear, therefore, to be unrelated to changes in the intestinal flora.
\end{abstract}

Research has established that the intestinal flora is an important determinant of mucosal structure (Abrams et al. 1963, Thompson \& Trexler, 1971). Compared with conventional animals, germ-free animals have a lower mitotic count in the crypt cells, decreased cell migration time, an increased proportion of mature mucosal cells and higher levels of disaccharidase activity (Abrams et al. 1963; Reddy \& Wostmann, 1966). The villi are thinner and more pointed toward the tip and there is a substantial decrease in mucosal surface area (Gordon \& Bruckner-Kardoss, 1961). In addition, glucose and xylose are absorbed more efficiently, the rate of gastric emptying is reduced, fluid absorption in the colon is impaired and there is an enlargement of the caecum in germ-free rodents (Heneghan, 1963; Abrams, 1977). The intestinal structural and functional characteristics associated with an absence of intestinal bacteria are, in many respects, strikingly similar to those observed in the zinc-deficient rat. Previous studies (Southon et al. 1984, 1985, 1986) revealed that dietary $\mathrm{Zn}$ depletion is associated with morphological and functional changes in the jejunum, which included shortening and narrowing of jejunal villi, a reduction in absorptive surface and an enhancement of carrier mediated hexose transport. These changes were accompanied by, and may be related to, a lower rate of mucosal cell proliferation and a probable slowing of cell migration along the villus.

$\mathrm{Zn}$ is a co-factor for a wide range of enzymes, including those associated with cell division, protein synthesis and carbohydrate metabolism in bacteria, and a deficiency under culture conditions can lead to reduced bacterial growth (Harris, 1969; Summers \& Srinivasan, 1979). There is a possibility, therefore, that the changes in mucosal structure and function observed in severely $\mathrm{Zn}$-deficient rats may be secondary to impaired microbial growth, resulting from the reduction in intralumenal $\mathrm{Zn}$ concentration. 
The present study was undertaken to investigate the effect of prolonged dietary $\mathrm{Zn}$ depletion, followed by a much shorter period of $\mathrm{Zn}$ supplementation, on microbial populations, morphology and the activity of selected enzymes in the intestine of the rat.

\section{MATERIALS AND METHODS \\ Animals and diets}

Immature male Wistar rats (approximately $105 \mathrm{~g}$ ) were divided into five groups of eight. Each of these groups contained one littermate, from eight batches of five littermates, to eliminate possible variation between groups due to familial differences in microbial populations. The rats were housed in pairs, to minimize stress, in polypropylene cages with stainless-steel lids and bottoms, in a room at $21^{\circ}$ having a $12 \mathrm{~h} \mathrm{light}-12 \mathrm{~h}$ dark cycle. The first group received a semi-synthetic diet containing $2 \mathrm{mg} \mathrm{Zn} / \mathrm{kg}$ diet for the duration of the study ( $\mathrm{Zn}$-deficient ( $\mathrm{ZD})$ group). The second group was maintained on a similar diet for $24 \mathrm{~d}$ followed by a $4 \mathrm{~d}$ period when they received a $\mathrm{Zn}$-supplemented diet containing $60 \mathrm{mg} \mathrm{Zn} / \mathrm{kg}$ (Zn-deficient - refed (ZDR) group). The third and fourth groups were given an amount of $\mathrm{Zn}$-supplemented diet equal to that consumed by a paired cage of $\mathrm{ZD}$ and ZDR rats respectively (feed-restricted (FR) group and feed-restricted - refed (FRR) group). Rats in these four groups were meal-fed in order to minimize differences in feeding patterns between groups. Meal-fed rats were given access to food for $3 \mathrm{~h}$ each day between 09.30 and 11.00 hours, and 16.00 and 17.30 hours. The fifth group received the $\mathrm{Zn}$-supplemented diet ad lib. (ad lib.-fed control (AL) group). The diet was a casein-starch-sucrose diet as previously described by Southon et al. 1984, with the addition of $5 \mathrm{mg}$ methionine $/ \mathrm{kg}$ diet. Distilled water was provided ad lib. Food intakes were measured daily and bodyweights recorded twice weekly at 09.00 hours. The body-weight gain of cage mates was compared at each weighing as an index of the relative amounts of food consumed by each individual. Equal numbers of ZD, FR and AL rats were killed between 11.00 and 15.00 hours on days 22, 23 and 24, and ZDR and FRR rats on days 28 and 29 of the study. All animals were allowed access to food on the the morning of the day they were killed.

\section{Collection of samples}

Animals were anaesthetized by intraperitoneal injection of sodium barbiturate (Sagatal; May \& Baker, Dagenham, Kent; $1 \mathrm{ml} / \mathrm{kg}$ body-weight). The abdomen was opened and the small intestine ligatured at the pyloric sphincter and ileo-caecal junction. The caecum was also isolated by ligaturing at the ileo-caecal and colono-caecal junctions. The small intestine was removed, and the length measured with minimal stretching. Further ligatures were placed $20 \mathrm{~mm}$ distally to the duodenal-jejunal junction (10\% of the small intestinal length), and $20 \mathrm{~mm}$ proximally to the ileo-caecal valve. The $20-\mathrm{mm}$ lengths were taken for morphological examination. The remaining isolated small intestine was transferred to an anaerobic cabinet (nitrogen-hydrogen-carbon dioxide $85: 10: 5$. by vol.) and the ligatures removed. Lumen contents and scraped mucosal tissue were transferred to individual pre-weighed bottles containing $10 \mathrm{ml}$ anaerobic dilution solution (ADS; Bryant \& Burkey, 1953) and a quantity of glass beads. The suspensions of small intestinal contents and scraped mucosa were reweighed and thoroughly mixed, by vortexing, for subsequent dilution and plating. A sample of the mucosal suspension was stored at $-20^{\circ}$ before determination of DNA, protein, moisture content and mucosal enzyme activity.

The isolated caecum was removed and weighed on a torsion balance, transferred to an anaerobic cabinet and slit open. A sample of caecal contents was removed for dilution and plating and the remainder was taken for wet and dry weight determinations. The caecal tissue was rinsed, blotted, reweighed, dried at $85^{\circ}$ for $18 \mathrm{~h}$ and weighed again. 


\section{Morphological study}

Samples of proximal jejunum and distal ileum obtained from animals in the microbiological study were fixed by immersion in a mixture of absolute ethanol and glacial acetic acid $(75: 25$, $\mathrm{v} / \mathrm{v})$, followed by storage in ethanol-water $(75: 25, \mathrm{v} / \mathrm{v})$. Each sample was stained in bulk by the Feulgen reaction (Clarke, 1970) and subsequently slit open, placed mucosal side uppermost and examined under a dissecting microscope fitted with a graduated eyepiece to provide measurements of intestinal width and villous density. Five separate estimates of the number of villi per unit area of serosa were made and averaged to give a single estimate for each animal. A total of ten villi were then removed from each sample by microdissection with sharpened needles. Estimates of the maximum height and basal width were made using the graduated eyepiece.

\section{Mucosal enzyme activity}

Mucosal suspensions in ADS were further diluted with saline ( $9 \mathrm{~g}$ sodium chloride/l) so that the ratio, fresh mucosa: diluent was approximately $1: 10$. The suspension was homogenized using an Ultraturrax (Janke and Kunkel KG, Staufen i $\mathrm{Br}$., West Germany), and the activities of alkaline phosphatase (EC 3.1.3.1), maltase (EC 3.2.1.20), lactase (EC 3.2.1.23) and sucrase (EC 3.2.1.48), and the protein, DNA and moisture contents were determined as described previously (Johnson et al. 1984).

\section{Microbiology study}

In the anaerobic cabinet, samples $(0.25 \mathrm{ml})$ from the small intestinal mucosal scrapes and lumen contents in ADS were combined with $4.5 \mathrm{ml}$ ADS, and further tenfold dilutions prepared in ADS. Suitable dilutions were plated $(0.05 \mathrm{ml})$ anaerobically on VLhlf agar (Croucher et al. 1983), a complex medium which recovers a high proportion of faecal organisms. Approximately $0.5 \mathrm{~g}$ of the caecal contents was added to ADS (10 ml) and mixed to form a slurry which was diluted and plated as described previously. Organisms were enumerated after incubation for $7 \mathrm{~d}$ at $37^{\circ}$. Both caecal and small intestinal samples were also plated aerobically on CLED agar (Oxoid Ltd, Basingstoke, Hampshire) and incubated at $37^{\circ}$ for up to $5 \mathrm{~d}$. CLED is a diagnostic medium which allows preliminary identification of facultative enteric bacteria and prevents swarming of Proteus sp.

\section{Statistical analysis}

The significance of differences between means for the ZD and FR groups, and for the ZDR and FRR groups, was estimated using Student's paired $t$ test. All other comparisons were made using Student's unpaired $t$ test. Average values for each cage of rats were compared, except for body-weight gain and food intake data (Table 1) where comparisons were made using total cage values.

\section{RESULTS}

The mean values for body-weight gain, food intake and food conversion efficiency are shown in Table 1. Rats given a low- $\mathrm{Zn}$ diet consumed on average $55 \%$ less food over the experimental period than the ad lib.-fed controls. The growth rate and food conversion efficiency of the feed-restricted controls were significantly greater than those of the ZD rats. Daily food intakes of the $\mathrm{ZD}$ rats rapidly returned to normal when $\mathrm{Zn}$ was added to the diet. The rate of body-weight gain and food utilization for both the ZD animals and their FR counterparts exceeded that for AL controls during this period of supplementation. Comparisons of individual rates of body-weight gain showed that growth rates of cage mates 
Table 1. Body-weight gain, food intake and food conversion efficiency for zinc-deficient $(Z D)$, feed-restricted control $(F R)$, ad lib.-fed control $(A L), Z D$-refed $(Z D R)$ and $F R-$ refed $(F R R)$ rats

(Values are means with their standard errors)

\begin{tabular}{|c|c|c|c|c|c|c|c|c|c|c|}
\hline \multirow[t]{2}{*}{ Dietary treatment $\uparrow \ldots$} & \multicolumn{2}{|c|}{$\mathrm{ZD}$} & \multicolumn{2}{|c|}{ FR } & \multicolumn{2}{|c|}{$\mathrm{AL}$} & \multicolumn{2}{|c|}{ ZDR } & \multicolumn{2}{|c|}{ FRR } \\
\hline & Mean & SE & Mean & SE & Mean & $\mathrm{SE}$ & Mean & SE & Mean & SE \\
\hline Body-wt gain $(\mathrm{g} / \mathrm{d}) \ddagger$ & $2 \cdot 2^{\mathrm{a}}$ & $0 \cdot 1$ & $3 \cdot 1^{\mathrm{b}}$ & $0 \cdot 3$ & $12 \cdot 4^{\mathrm{c}}$ & $0 \cdot 3$ & $17 \cdot 3^{d}$ & $1 \cdot 3$ & $16 \cdot 5^{d}$ & $1 \cdot 5$ \\
\hline Food intake $(\mathrm{g} / \mathrm{d})+$ & $13 \cdot 4^{\mathrm{a}}$ & $0 \cdot 3$ & $13 \cdot 6^{\mathrm{a}}$ & $0 \cdot 3$ & $29 \cdot 9^{\mathrm{b}}$ & 0.6 & $32 \cdot 5^{\mathrm{b}}$ & $1 \cdot 8$ & $31 \cdot 3^{b}$ & 1.8 \\
\hline $\begin{array}{l}\text { Food conversion } \\
\text { efficiency } \ddagger\end{array}$ & $16^{\mathrm{a}}$ & 1 & $23^{b}$ & 2 & $41^{\mathrm{c}}$ & 1 & $53^{\mathrm{d}}$ & 3 & $53^{d}$ & 7 \\
\hline
\end{tabular}

a, b, c, d Mean values with unlike superscript letters within a horizontal line were significantly different $(P<0 \cdot 05)$.

+ For details of dietary treatment, see p. 604.

$\ddagger$ Daily body-weight gain, food intake and food conversion efficiency ((body-weight gain/food intake) $\times 100)$ of pairs of animals during the first $21 \mathrm{~d}$ feeding period for ZD, FR (eight pairs per group) and AL (four pairs) rats, and during a subsequent $4 \mathrm{~d}$ refeeding period for ZDR and FRR (four pairs per group) rats.

Table 2. Small intestinal dimensions, weight of mucosa, weight of caecum and caecal contents for zinc-deficient $(Z D)$, feed-restricted control $(F R)$, ad lib.-fed control $(A L), Z D$ - refed $(Z D R)$ and $F R-$ refed $(F R R)$ rats

(Values are means with their standard errors for four pairs of rats per group)

\begin{tabular}{|c|c|c|c|c|c|c|c|c|c|c|}
\hline \multirow[t]{2}{*}{ Dietary Treatment $\uparrow \ldots$} & \multicolumn{2}{|c|}{$\mathrm{ZD}$} & \multicolumn{2}{|c|}{ FR } & \multicolumn{2}{|l|}{$\mathrm{AL}$} & \multicolumn{2}{|c|}{ ZDR } & \multicolumn{2}{|c|}{ FRR } \\
\hline & Mean & $\mathrm{SE}$ & Mean & $\mathrm{SE}$ & Mean & $\mathrm{SE}$ & Mean & $\mathrm{SE}$ & Mean & SE \\
\hline $\begin{array}{l}\text { Small intestinal } \\
\text { length }(\mathrm{mm})\end{array}$ & $960^{2}$ & 10 & $970^{\mathrm{a}}$ & 10 & $1090^{b}$ & 10 & $990^{\mathrm{a}}$ & 20 & $970^{\mathrm{a}}$ & 20 \\
\hline \multicolumn{11}{|l|}{$\begin{array}{l}\text { Small intestinal } \\
\text { circumference }(\mathrm{mm}) \text { : }\end{array}$} \\
\hline Jejunum & $7 \cdot 5^{\mathrm{a}}$ & $0 \cdot 2$ & $7 \cdot 5^{\mathrm{a}}$ & 0.2 & $8 \cdot 4^{b}$ & 0.1 & $8 \cdot 3^{\mathrm{b}}$ & 0.1 & $7 \cdot 9^{\mathrm{ab}}$ & $0 \cdot 3$ \\
\hline Ileum & $7 \cdot 3^{\mathrm{a}}$ & $0 \cdot \overline{3}$ & $7 \cdot 2^{\mathrm{a}}$ & 0.4 & $8 \cdot 4^{b}$ & $0 \cdot 3$ & $7 \cdot 9^{\mathrm{a}}$ & $0 \cdot 3$ & $8 \cdot 1^{a}$ & 0.2 \\
\hline \multicolumn{11}{|l|}{ Dry wt $(\mathrm{mg})$ of: } \\
\hline $\begin{array}{l}\text { Small intestinal } \\
\text { mucosa }\end{array}$ & $184^{a}$ & 16 & $206^{\mathrm{a}}$ & 20 & $324^{b}$ & 10 & $286^{\mathrm{c}}$ & 9 & $276^{\mathrm{c}}$ & 7 \\
\hline Caecal tissue & $108^{\mathrm{a}}$ & 9 & $128^{\mathrm{a}}$ & 14 & $335^{b}$ & 32 & $223^{\mathrm{c}}$ & 10 & $196^{\mathrm{c}}$ & 16 \\
\hline Caecal contents & $450^{\mathrm{a}}$ & 40 & $490^{a}$ & 30 & $630^{\mathrm{b}}$ & 30 & $520^{\mathrm{a}}$ & 30 & $560^{\mathrm{a}}$ & 50 \\
\hline
\end{tabular}

a, b, c Mean values with unlike superscript letters within a horizontal line were significantly different $(P<0.05)$.

$\dagger$ For details of dietary treatment, see p. 604.

within each group were similar, indicating that there were no large variations in food intakes between rats housed together.

\section{Morphological study}

Values for total dry weights of mucosa, caecal tissue and caecal contents, and small intestinal dimensions for the ZD and FR control rats were all lower than those for AL controls. Mean values for small intestinal circumference and mucosal dry weight significantly increased in 


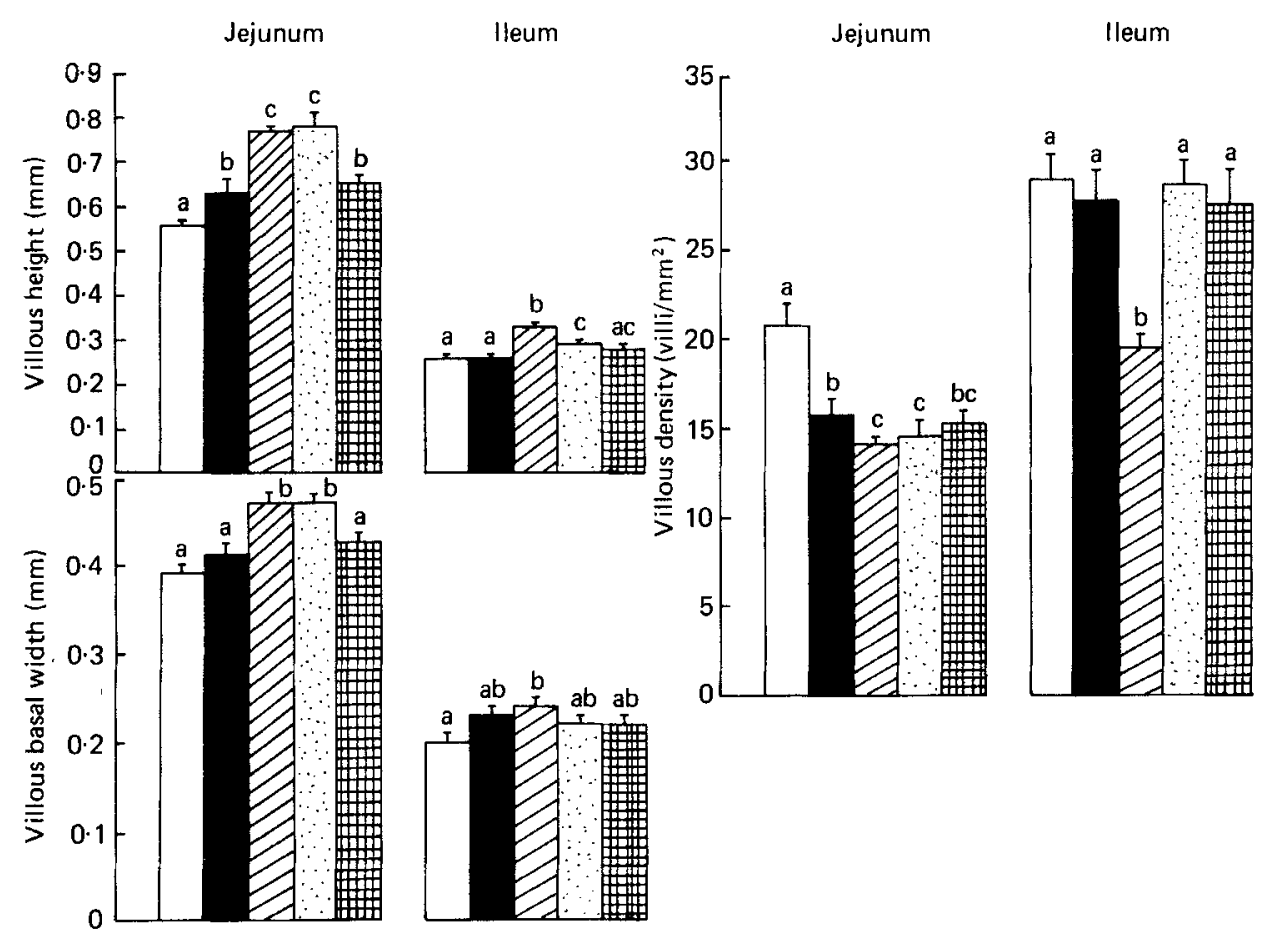

Fig. 1. Morphology of microdissected villi from zinc-deficient (ZD) and Zn-supplemented rats. ZD ( $\square$ ), feed-restricted ( $\square$ ), ad lib.-fed control (圆), ZD - refed(圈), feed-restricted - refed (霸) rats. For details of dietary treatment, see p. 604. Values are means with their standard errors, represented by vertical bars, for four pairs of rats per group. ${ }^{a, b}$, e Mean values with unlike superscript letters were significantly different $(P<0 \cdot 05)$.

both the $\mathrm{ZD}$ rats and their FR counterparts following the period of $\mathrm{Zn}$ supplementation and increased food consumption (Table 2).

The villi of proximal jejunum and distal ileum from $Z D$ and FR control rats were shorter, narrower and present in larger numbers per unit area of serosa than those of AL controls. Changes in villous dimensions and density were, however, more marked in the ZD animals (Fig. 1). There was a substantial decrease in villous density, and increase in maximum height and basal width of individual villi in the jejunum of $\mathrm{ZD}$ rats after $\mathrm{Zn}$ supplementation, compared with the non-supplemented animals. Changes occurred in a similar direction in the ileum following $\mathrm{Zn}$ supplementation, but to a very much lesser extent (Fig. 1). FR rats appeared to respond more slowly during the $4 \mathrm{~d}$ period of increased food consumption, the only significant change being a small reduction in villous density in the jejunum (Fig. 1).

Dry weight of caecal tissue and contents increased significantly over the refeeding period in both the $\mathrm{ZD}$ and FR rats, but did not reach the value for AL controls (Table 2).

Small intestinal mucosal alkaline phosphatase activity was lowest in the $\mathrm{ZD}$ rats (Table 3). Disaccharidase activities were lower in the ZD group, compared with their FR counterparts, but were similar to values for the $\mathrm{AL}$ controls. Total tissue alkaline phosphatase and disaccharidase activities (units/mg protein) were consistently higher after a $4 \mathrm{~d}$ period of $\mathrm{Zn}$ supplementation, compared with non-supplemented animals, but the increase was only significant for alkaline phosphatase. The greater differences in enzyme activity between the ZD and ZDR groups, when expressed in terms of DNA, were due to changes in the DNA:protein value. Disaccharidase activities tended to be higher in mucosa 
Table 3. Mucosal enzyme activity, and protein and DNA contents in zinc-deficient $(Z D)$, feed-restricted control $(F R)$, ad lib.-fed control $(A L)$. $Z D$ - refed $(Z D R)$ and $F R$-refed (FRR) rats

(Values are means with their standard errors for four pairs of rats per group)

\begin{tabular}{|c|c|c|c|c|c|c|c|c|c|c|}
\hline \multirow[t]{2}{*}{ Dietary treatment $\dagger \ldots$} & \multicolumn{2}{|c|}{$\mathrm{ZD}$} & \multicolumn{2}{|l|}{ FR } & \multicolumn{2}{|l|}{$\mathrm{AL}$} & \multicolumn{2}{|l|}{ ZDR } & \multicolumn{2}{|l|}{ FRR } \\
\hline & Mean & SE & Mean & $\mathrm{SE}$ & Mean & SE & Mean & SE & Mean & $\mathrm{SE}$ \\
\hline Protein (mg/g dry wt) & $458^{\mathrm{a}}$ & 14 & $432^{\mathrm{ac}}$ & 10 & $364^{b}$ & 13 & $461^{a e}$ & 25 & $407^{\mathrm{c}}$ & 10 \\
\hline DNA (mg/g dry wt) & $28 \cdot 6^{\mathrm{a}}$ & $1 \cdot 8$ & $25 \cdot 5^{\mathrm{ab}}$ & $3 \cdot 5$ & $23 \cdot 2^{\mathrm{ab}}$ & $2 \cdot 0$ & $22 \cdot 5^{\mathrm{b}}$ & $1 \cdot 2$ & $23 \cdot 9^{\mathrm{ab}}$ & $1 \cdot 1$ \\
\hline \multicolumn{11}{|c|}{ Enzyme activity (munits/mg protein): } \\
\hline $\begin{array}{l}\text { Alkaline phosphatase } \\
(E C \text { 3.1.3.1) }\end{array}$ & $62^{\mathrm{a}}$ & 7 & $105^{\mathrm{b}}$ & 14 & $138^{b}$ & 13 & $117^{\mathrm{b}}$ & 7 & $116^{\mathrm{b}}$ & 5 \\
\hline $\begin{array}{l}\text { Maltase } \\
(E C \text { 3. 2.1.20) }\end{array}$ & $637^{a}$ & 37 & $720^{\mathrm{be}}$ & 29 & $618^{\mathrm{a}}$ & 29 & $656^{\mathrm{ab}}$ & 28 & $604^{a}$ & 23 \\
\hline $\begin{array}{l}\text { Sucrase } \\
(E C 3.2 .1 .48)\end{array}$ & $42^{a}$ & 3 & $50^{\mathrm{b}}$ & 3 & $43^{\mathrm{ab}}$ & 5 & $50^{\mathrm{ab}}$ & 6 & $51^{\mathbf{a b}}$ & 5 \\
\hline $\begin{array}{l}\text { Lactase } \\
(E C 3.2 .1 .23)\end{array}$ & $8 \cdot 6^{a}$ & $1 \cdot 0$ & $10 \cdot 3^{b}$ & 0.7 & $7 \cdot 8^{\mathrm{a}}$ & $0 \cdot 7$ & $9 \cdot 9^{\mathrm{ab}}$ & $0 \cdot 7$ & $10 \cdot 4^{\mathrm{ab}}$ & 0.5 \\
\hline \multicolumn{11}{|c|}{ Enzyme activity (units/mg DNA): } \\
\hline Alkaline phosphatase & $1 \cdot 0^{\mathrm{a}}$ & $0 \cdot 1$ & $1 \cdot 8^{\mathrm{b}}$ & $0 \cdot 3$ & $2 \cdot 2^{\mathrm{b}}$ & $0 \cdot 3$ & $2 \cdot 4^{b}$ & $0 \cdot 5$ & $2 \cdot 0^{\mathrm{b}}$ & $0 \cdot 7$ \\
\hline Maltase & $10 \cdot 2^{\mathrm{a}}$ & 0.9 & $12 \cdot 2^{\mathrm{ab}}$ & $1 \cdot 3$ & $9 \cdot 7^{a}$ & $1 \cdot 1$ & $13 \cdot 4^{b}$ & $0 \cdot 6$ & $10 \cdot 3^{a}$ & 0.6 \\
\hline Sucrase & $0 \cdot 67^{\mathrm{a}}$ & 0.06 & $0.85^{\mathrm{ab}}$ & 0.09 & $0.74^{\mathrm{ab}}$ & 0.19 & $1 \cdot 15^{b}$ & $0 \cdot 16$ & $0.86^{a b}$ & 0.09 \\
\hline Lactase & $0 \cdot 14^{a}$ & 0.02 & $0 \cdot 17^{\mathrm{ab}}$ & 0.03 & $0 \cdot 12^{\mathrm{a}}$ & 0.02 & $0 \cdot 20^{\mathrm{bc}}$ & c 0.01 & $0 \cdot 18^{\mathrm{ac}}$ & 0.01 \\
\hline
\end{tabular}

a, b, c Mean values with unlike superscript letters within a horizontal line were significantly different $(P<0 \cdot 05)$.

† For details of dietary treatment, see p. 604.

Table 4. Bacterial populations in small and large intestine of zinc-deficient $(Z D)$, feed-restricted control $(F R)$ ad lib.-fed control $(A L), Z D$ - refed $(Z D R)$ and $F R$ - refed $(F R R)$ rats

(Values are expressed as logarithm $\mathrm{m}_{10}$ of the means with their standard errors for four pairs of rats per group)

\begin{tabular}{|c|c|c|c|c|}
\hline \multirow{3}{*}{$\begin{array}{c}\text { Dietary } \\
\text { treatment } \uparrow\end{array}$} & \multicolumn{4}{|c|}{ Total viable counts $\left(\log _{10}\right)$} \\
\hline & \multicolumn{2}{|c|}{ Anaerobes } & \multicolumn{2}{|c|}{ Facultative aerobes } \\
\hline & Mean & SE & Mean & $\mathrm{SE}$ \\
\hline \multicolumn{5}{|l|}{ Small intestine } \\
\hline $\mathrm{ZD}$ & $9 \cdot 5^{\mathrm{u}}$ & 0.08 & $8 \cdot 7^{\mathrm{ab}}$ & 0.49 \\
\hline FR & $9 \cdot 8^{\mathrm{a}}$ & 0.34 & $8 \cdot 7^{a b}$ & 0.43 \\
\hline $\mathrm{AL}$ & $9 \cdot 8^{\mathrm{ab}}$ & 0.41 & $8 \cdot 7^{\mathrm{a}}$ & $0 \cdot 23$ \\
\hline ZDR & $8 \cdot 4^{\mathrm{b}}$ & $0 \cdot 11$ & $7 \cdot 8^{b}$ & 0.46 \\
\hline FRR & $9 \cdot 8^{\mathrm{ab}}$ & 0.69 & $8 \cdot 3^{a b}$ & $0 \cdot 30$ \\
\hline \multicolumn{5}{|l|}{ Caecum $\S$} \\
\hline $\mathrm{ZD}$ & $11 \cdot 2^{\mathrm{a}}$ & 0.57 & $9 \cdot 8^{\mathrm{a}}$ & $0 \cdot 20$ \\
\hline FR & $11 \cdot 2^{\mathrm{a}}$ & 0.60 & $9.9^{a}$ & $0 \cdot 30$ \\
\hline $\mathrm{AL}$ & $11 \cdot 2^{\mathrm{a}}$ & 0.56 & $9.9^{a}$ & $0 \cdot 32$ \\
\hline $\mathrm{ZDR}$ & $11 \cdot 1^{\mathrm{a}}$ & 0.49 & $9.9^{a}$ & 0.49 \\
\hline FRR & $11 \cdot 1^{\mathrm{a}}$ & 0.38 & $10 \cdot 0^{\mathrm{a}}$ & 0.49 \\
\hline
\end{tabular}

a,b Mean values with unlike superscript letters within a vertical column were significantly different $(P<0 \cdot 05)$.

$\dagger$ For details of dietary treatment, see p. 604.

$\mp$ Counts obtained from luminal contents plus mucosal tissue.

$\$$ Counts obtained from caecal contents. 
from FR rats compared with AL controls. After $4 \mathrm{~d}$ of increased food consumption, the mean value for maltase activity had significantly decreased but the activities of sucrase and lactase were virtually unchanged (Table 3 ).

\section{Microbiological study}

Viable counts of both anaerobic and facultatively aerobic bacteria in caecal contents varied little between dietary treatments (Table 4). Greater variation was observed in the small intestine, particularly in the counts of facultative aerobes (Table 4). Any differences between groups in the size of the intestinal microbial population were similar whether values were expressed in terms of concentration (counts/g dry weight of contents or contents plus mucosa) or in terms of total population, hence only the latter values are provided. Both the concentration and total population of bacteria were lower in the small intestine of rats recovering from dietary $\mathrm{Zn}$-depletion, compared with the other four groups (Table 4). No other differences were observed. The intestinal floras from all groups of rats appeared to be similar, the same colony types being observed in each case.

\section{DISCUSSION}

The basic mechanisms involved in the regulation of epithelial renewal and mucosal structure are largely unknown. However, the intestinal bacterial flora has been shown to be an important determinant of both the structural and functional characteristics of the mucosa (Thompson \& Trexler, 1971). Mucosal surface area and morphology, epithelial renewal, mucosal enzyme activity, rates of glucose and xylose absorption, caecal size and resistance to infection, are all influenced by the presence or absence of an intestinal flora (Gordon \& Bruckner-Kardoss, 1961; Heneghan, 1963; Abrams \& Bishop, 1967). In many respects the mucosal characteristics of germ-free and ZD rats are very similar. Both groups of animals exhibit depressed rates of cellular proliferation in the mucosal epithelium, reductions in villous dimensions and mucosal surface area, and a marked enhancement of glucose transport (Southon et al. 1984, 1985). Since Zn has been shown to be an important factor in cell replication and growth in several species of micro-organisms, including Escherichia coli (Harris, 1969; Valle \& Falchuk, 1981), it seemed possible that changes in the availability of intra-lumenal $\mathrm{Zn}$ might result in fluctuations in the size of the intestinal bacterial population. The changes in mucosal growth observed in ZD rats might, therefore, be secondary to impaired microbial growth. The present study establishes that even severe restriction of dietary $\mathrm{Zn}$ intake has no significant effect on either the size of the intestinal microbial population or on the major colony types isolated. There was also no evidence that the increased growth response of the mucosa to subsequent $\mathrm{Zn}$ supplementation was linked to an increase in bacterial growth; in fact bacterial counts from small intestinal samples were consistently lower for this group of animals. It was considered that this decrease in small intestinal population might be associated with the dramatic increase in food consumption which occurred during the refeeding period, since a rapid and substantial increase in the quantity of food moving through the intestinal tract might be expected to result in a redistribution of the resident flora. There was, however, no indication that this had occurred in the FR control rats. Since the amount of food consumed by the ZD and FR rats was substantially lower than normal, it is likely that faecal mass and bacterial output were reduced in both these groups compared with the AL controls, although the intestinal bacterial population at one time was found to be similar in all groups. The importance of the total bacterial mass produced in the intestine for the determination of mucosal characteristics is not known, but in this instance it is unlikely to account for differences in the response of the mucosa to dietary $\mathrm{Zn}$ deficiency and feed restriction.

The present study also demonstrates that the mucosa responds rapidly to the reintroduction 
of optimal levels of $\mathrm{Zn}$ to the diet, as does appetite, growth rate and food utilization. Growth rate and food conversion efficiency of both the $\mathrm{ZD}$ rats and their FR counterparts, over the $4 \mathrm{~d}$ refeeding period, exceeded that normally observed in AL controls. Changes in the structure of jejunal mucosa of $\mathrm{ZD}$ and FR control rats were similar to those described in previous studies (Southon et al. 1984, 1986). After $4 \mathrm{~d}$ of $\mathrm{Zn}$ supplementation, mean values for small intestinal circumference and villous dimensions in the jejunum were significantly higher, and villous density in the jejunum was significantly lower, than those for the non-supplemented $\mathrm{ZD}$ rats, and were similar to values for AL controls. We have postulated that alterations in mucosal growth in $\mathrm{ZD}$ rats may be a direct result of a reduction in cellular proliferation in the crypt cells (Southon et al. 1985). It would therefore be of interest to determine whether the recovery in mucosal growth was associated with an increase in epithelial renewal in the jejunum.

A decrease in villous dimensions and increase in villous density was observed in the ileal mucosa of ZD and FR rats when compared with AL controls but, as in the jejunum, these changes were greater in the ZD animals. There was little change in villous density and the basal width of individual villi after the refeeding period, but the value for villous height in the ileum was significantly greater in rats recovering from dietary $\mathrm{Zn}$ depletion, compared with the non-supplemented group. It has been demonstrated that the efficiency of $\mathrm{Zn}$ absorption is significantly greater in ZD rats than in normal animals (Jackson et al. 1981), and that most of this $\mathrm{Zn}$ is absorbed in the proximal small intestine (Davies, 1980). It is possible, therefore, that the rate of tissue repletion was slower in the distal region of the gut, with a consequently slower recovery of normal mucosal structure.

The changes in mucosal morphology in rats recovering from experimental $\mathrm{Zn}$ deficiency appeared to result, primarily, from increased dietary $\mathrm{Zn}$ intake since their FR counterparts did not exhibit the same degree of response during the period of increased food consumption. It may be argued that the FR controls, which received a restricted amount of the $\mathrm{Zn}$-adequate diet and consequently reduced $\mathrm{Zn}$ intakes compared with the $\mathrm{AL}$ controls, may be marginally $\mathrm{Zn}$-deficient. Changes in growth rate, food utilization and mucosal morphology might, therefore, be associated with reduced $\mathrm{Zn}$ intake as well as reduced food consumption. Normal plasma and femur $\mathrm{Zn}$ concentrations, and the absence of any overt symptoms of the deficiency, indicate that the Zn status of the FR animals was normal (Southon et al. 1982, 1984). The assessment of $\mathrm{Zn}$ status, however, is notoriously difficult and the possibility of a marginal deficiency state in these animals, particularly during periods of extreme nutrient restriction, cannot be excluded.

The massive enlargement of the caecum, and the increase in mucosal enzyme activity. characteristic of gnotobiotic animals (Thompson \& Trexler, 1971), did not occur in ZD rats; indeed, disaccharidase activities were significantly lower in the mucosa of ZD rats compared with FR controls, and appeared to increase following $\mathrm{Zn}$ supplementation. Differences in disaccharidase activity between the ZD and FR groups were, however, only significant when estimated using a paired $t$ test. Values for ZD rats were consistently lower than those for their paired FR counterparts but, as with food intake, between-pair values within a group were highly variable. This suggests that these enzymes are sensitive to the level of food intake. As expected, there was a decline in mucosal alkaline phosphatase activity in rats given the low-Zn diet and the activity of this enzyme returned to normal levels during the period of recovery. In view of the discussion on the $\mathrm{Zn}$ status of FR rats, it is interesting to note that there was also an indication of lower mucosal alkaline phosphatase activity in feed-restricted controls, although the level of food intake has been reported to be without effect on the activity of this enzyme (Luecke et al. 1968; Williams, 1972). The significance of these changes in mucosal enzyme activities has yet to be determined.

Clearly there is no indication that alterations in intestinal structure resulting from 
variations in dietary $\mathrm{Zn}$ concentration are associated with fluctuations in the resident microbial population. The factors influencing mucosal growth and function are poorly understood, but it is likely that the rate of cell production, migration and loss are important determinants of both (de Both et al. 1974). Similarities in the mucosal characteristics of gnotobiotic and $\mathrm{ZD}$ rats may, therefore, be linked to a reduction in villous cell influx, a feature common to both groups of animals.

The authors thank Mrs J. Cooke and Mr P. Muddel for skilled animal care, and Miss J. Brown and Miss K. A. Hamand for technical assistance.

\section{REFERENCES}

Abrams, G. D. (1977). American Journal of Clinical Nutrition 30, 1880-1886.

Abrams, G. D., Bauer, H. \& Sprinz, H. (1963). Laboratory Investigation 12, 355-364.

Abrams, G. D. \& Bishop, J. E. (1967). Proceedings of the Society of Experimental and Biological Medicine 126, 301-304

Bryant, M. P. \& Burkey, L. A. (1953). Journal of Dairy Science 36, 205-217.

Clarke, R. M. (1970). Journal of Anatomy 107, 519-529.

Croucher, S. C., Houston, A. P., Bayliss, C. E. \& Turner, R. J. (1983). Applied and Environmental Microbiology 45, 1025-1033.

Davies, N. T. (1980). British Journal of Nutrition 45, 189-203.

de Both, N. J., van Dongen, J. M., van Hofwegen, B., Keuleman, J., Visser, W. J. \& Galjaard, H. (1974). Developmental Biology 38, 119-137.

Gordon, H. A. \& Bruckner-Kardoss, E. (1961). American Journal of Physiology 201, 175-178.

Harris, A. B. (1969). Journal of General Microbiology 52, 27-33.

Heneghan, J. B. (1963). American Journal of Physiology 205, 417-420.

Jackson, M. J., Jones, D. A. \& Edwards, R. H. (1981). British Journal of Nutrition 52, 477-487.

Johnson, I. T., Gee, J. M. \& Mahoney, R. R. (1984). British Journal of Nutrition 52, 477-487.

Luecke, R. W., Olman, M. E. \& Baltzer, B. V. (1968). Journal of Nutrition 94, 344-350.

Reddy, B. S. \& Wostmann, B. S. (1966). Archives of Biochemistry 113, 609-616.

Southon, S., Gee, J. M. \& Johnson, I. T. (1984). British Journal of Nutrition 52, 371-380.

Southon, S., Gee, J. M. \& Johnson, I. T. (1986). British Journal of Nutrition 55, 193-200.

Southon, S., Johnson, I. T., Gee, J. M. \& Gee, M. G. (1982). Proceedings of the Nutrition Society 41, 134A.

Southon, S., Livesey, G., Gee, J. M. \& Johnson, I. T. (1985). British Journal of Nutrition 53, 595-603.

Summers, R. J. \& Scrinivasan, V. R. (1979). Applied and Environmental Microbiology 37, 1079-1084.

Thompson, G. R. \& Trexler, P. C. (1971). Gut 12, 230-235.

Valle, B. L. \& Falchuk, K. H. (1981). Philosophical Transactions of the Royal Society 294, 185-197.

Williams, R. B. (1972). British Journal of Nutrition 27, 121-130. 